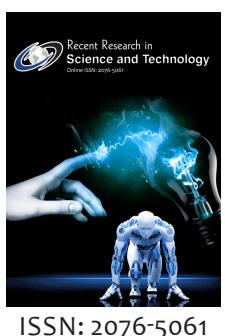

*Corresponding Author: Shafiqua Nawrin Oishi Email: shafiquanawrin@gmail. com

\section{Risk factors associated with Acute Respiratory Infection (ARI) among children under 10-years in Rohingya refugee camp}

\author{
Shafiqua Nawrin Oishi*, Nazmul Alam \\ Asian University for Women (AUW), 20/A M.M. Ali Road, Chittagong -4000, Bangladesh
}

\begin{abstract}
Acute respiratory infections are cause by bacterial, fungal or viral infections of the respiratory tract. Very young and older aged people are most vulnerable of these infections lead to difficulties from fever, cough, nasal discharge, sputum production, fatigue, wheezing, pain on swallowing, at times ear infections and meningitis. With huge number of Rohingya influx in Bangladesh, camps are overly crowded allowing many infectious diseases to transmit easily. Although there are researches that have been conducted in this area, there remains a huge gap of research in these camps where children being vulnerable are mostly suffering from respiratory disease such as Acute Respiratory Infection (ARI). This cross-sectional study investigated the risk factors associated with ARI among children less than 10 years in Rohingya refugee camps. After collecting information based on their demographic, anthropometric, history of respiratory problem, accommodation and nutritional status, it was found that about $21.6 \%$ of 259 children under this study had symptoms of ARI. Living in congested housing and with lack of nutritious food children were found negatively associated with ARI.
\end{abstract}

KEYWORDS: ARI, Rohingya, refugee, children, risk-factor

\section{INTRODUCTION}

According to WHO, Acute Respiratory Infection (ARI) is among the most crucial cause of both infant and young children mortality worldwide. Acute respiratory infections are cause by bacterial, fungal or viral infections of the respiratory (Banda et al. 2016). In very young and older aged group people these infections lead to difficulties including fever, cough, nasal discharge, sputum production, fatigue, wheezing, pain on swallowing and at times ear infections and infections in the membranes surrounding the brain (ibid). Due to ARI, about 12 million children, many during their first year but most before reaching their fifth birthday die every year in the developing countries (Gahlot et al. 2015).

In the recent context, International Organization of Migration (IOM) estimates that nearly 5,00,000 refugees have arrived in Bangladesh since violence broke out in Myanmar's northern Rakhine state and the total estimated number of Rohingya in Bangladesh is nearly 1 million including both registered and newly arrived people (Europa 2017). According to UNHCR there are nearly 30,000 registered refugees living in two official camps Kutupalong and Noyapara, managed by UN Refugee Agency recognized by the government of Bangladesh.

With this huge number of Rohingya fleeing to Bangladesh, camps are overly crowded allowing many infectious diseases to transmit easily. Although there are researches that have been conducted in this area, there remains a huge gap of research in those camps where children being vulnerable are mostly suffering from diseases such as ARI. This paper proposes a study to investigate the risk factors associated with ARI among children less than 10 years in Rohingya refugee camps.

\section{METHODOLOGY}

\section{Study Design}

The study used Cross Sectional Exploratory Study.

\section{Study Site}

The study was conducted in Make Shift camp no. 7 of Kutupalong Rohingya camp in Cox's Bazar, Bangladesh. 


\section{Study Population}

The target group being children under 10 years of age, the study was conducted among the boys and girls who have been living in the camps for at least one month in camp no. 7 where parents of the children responded to the questionnaire.

\section{Sampling Method}

Kutupalong Rohingya camp is the one of the only two registered camp for the refugees. The camp was still a newly made and extending almost every day, due to security concerns and navigating inside the camp, going alone was strictly discouraged. In addition to that, language barrier was another big issue that had to be tackled. BRAC being actively working in the Rohingya camp since the beginning of the crisis, had been reached out reached out to for assistance in translation and guidance inside the camp. With permission from Team Leader, BRAC, two camps were visited. Keeping in mind the accessibility, security and availability of the translator camp 7 was suggested by the camp officials of BRAC working in the camp.

\section{Sample Size}

The prevalence of ARI among south-east Asian countries varies from about $20-59 \%$. For sake of calculation 58.7\% (Goel at al. 2012) was taken and to calculate the sample size $6 \%$ absolute precision and $95 \%$ confidence level were considered. By calculating this from a readymade table the desired sample size was 259 .

\section{Data Collection}

A questionnaire was developed into four parts for the purpose of this study. First part of the questionnaire contained sociodemographic questions like; their age, location, family members etc. Second part of questionnaire had anthropometric information like; their height, weight, head circumference etc. Third part of the questionnaire focused on their symptoms, history of respiratory issues, allergy, history of delivery, birth weight, mother's/father's smoking habit (if any). Fourth part of the questionnaire was focus on their living condition, housing, eating habits etc. All data was collected through face-to-face interviews from mothers willing to provide information or their local guardian.

\section{Data Analysis}

SPSS 20.0 software was used for data analysis. A descriptive analysis was performed to understand the SES conditions, ARI symptoms, risk factors of ARIs. Chi-square, t-test and regression analysis were done to determine the relationship of the key variables addressing the specific objectives set forward for this study.

\section{RESULT}

The number of the participants was 259, with 135 male and 124 female children. Among the study sample, 56 (21.6\%) were suspected to have ARI where 28 were male and 28 female children. This variable was created merging two variables which reported children with chronic cough and having repetitive respiratory problems. The differential analysis of the sociodemographic risk factors of ARI with respect to their sex among children is illustrated in Table 1.

In binary logistic regression, age of the participants was found to a significant predictor of ARI with ones aging 13-60 months having crude odds ratio of 5.07 and adjusted being 8.39 (Table 2). Besides, the participant's medical history of having asthma showed significance and was found to have association with ARI. It was found that participants who reported having no allergy was at 4.66 times at risk of having ARI than who had allergy and when adjusted the risk of having ARI was 6.41 times among the participants with no allergies. As a large number of people had been living in small area inside the camp, it was seen that the risk of having ARI was 2.4 times (CI: 0.98 - 5.82; p-value 0.05 ) greater among ones who shared the room with more than 3 people. However, when adjusted the risk increased to 7.24 times but did not show significance. Other variables such as sex, smoking at home, intake of protein in the last meal did not show any significance in the test.

A checklist of symptoms was created in one section of the questionnaire and the parents were asked if their children are

Table 1: Socio-demographic characteristics of the study population

\begin{tabular}{|c|c|c|c|c|}
\hline Socio-economic variables & Male n (\%) & Female $\mathrm{n}(\%)$ & Total n (\%) & Chi-square/p-value \\
\hline \multicolumn{5}{|l|}{ Age } \\
\hline 1-12 months & $15(37.50)$ & $25(62.50)$ & 40 & $4.79 / 0.09$ \\
\hline 13-60 months & $83(56.80)$ & $63(43.20)$ & 146 & \\
\hline 61-119 months & $37(50.70)$ & $36(49.30)$ & 73 & \\
\hline \multicolumn{5}{|l|}{ Education level of the child } \\
\hline Currently enrolled & $48(36.60)$ & $45(33.30)$ & 93 & $1.16 / 0.56$ \\
\hline No education & $15(11.10)$ & $9(7.30)$ & 24 & \\
\hline Not applicable & $72(53.30)$ & $70(56.50)$ & 142 & \\
\hline \multicolumn{5}{|l|}{ Guardian's level of education } \\
\hline Had schooling & $17(12.60)$ & $12(9.70)$ & 29 & $0.55 / 0.45$ \\
\hline No education & $118(87.40)$ & $112(90.30)$ & 230 & \\
\hline \multicolumn{5}{|l|}{ Family members } \\
\hline 5 or less members & $56(41.05)$ & $54(43.50)$ & 110 & $2.41 / 0.29$ \\
\hline 6-10 members & $74(54.80)$ & $69(55.60)$ & 143 & \\
\hline 11 and above & $5(3.70)$ & $1(0.80)$ & 6 & \\
\hline
\end{tabular}


Table 2: Binary logistic regression of ARI with other variables

\begin{tabular}{|c|c|c|c|c|c|c|}
\hline Factor & Crude odds ratios & $95 \% \mathrm{CI}$ & $p$-value & Adjusted odds ratios & $95 \% \mathrm{CI}$ & $\mathrm{p}$-value \\
\hline \multicolumn{7}{|l|}{$\overline{\text { Age }}$} \\
\hline \multicolumn{7}{|l|}{ 1-12 months } \\
\hline $13-60$ months & 5.07 & $1.80-14$ & 0.00 & 8.39 & $1.50-46.78$ & 0.01 \\
\hline $61-119$ months & 2.97 & $1.25-7.07$ & 0.01 & 2.57 & $0.90-8.41$ & 0.07 \\
\hline \multicolumn{7}{|l|}{ Sex } \\
\hline \multicolumn{7}{|l|}{ Male } \\
\hline Female & 0.89 & $0.49-1.62$ & 0.71 & 1.09 & $0.51-2.33$ & 0.81 \\
\hline \multicolumn{7}{|l|}{ Asthma } \\
\hline \multicolumn{7}{|l|}{ Yes } \\
\hline No & 0.02 & $0.00-0.20$ & 0.00 & 0.04 & $0.00-0.41$ & 0.00 \\
\hline \multicolumn{7}{|l|}{ Any allergy } \\
\hline Yes & & & & & & \\
\hline No & 4.66 & $1.71-12.74$ & 0.00 & 6.41 & $1.18-34.65$ & 0.03 \\
\hline
\end{tabular}

having any of the symptoms in the checklist. Their history of any respiratory problem was also noted. It was seen that about $122(47.10 \%)$ of the total participants have been coughing for more than 2 weeks at least where about $54 \%$ were male children. In addition to that, 133 of the participants reported having history of respiratory problem most of them noted having pneumonia after reaching to Bangladesh.

For evaluating their nutritional status and food habit, when asked about their protein intake in their meals the previous day 125 responded yes, where with an exception of not more than 10 , the rest reported having dry fish as their share of protein. Within the total population only 4 which is just $1.54 \%$ $(\mathrm{p}<0.05)$ of the total sample reported having protein at least 5 times a week and showed significant. Even though, fruit/ vegetable intake was comparatively high among the participants with about 167 reporting of having vegetables and fruits at least 5 times last week, the intake of dairy product was found to be very low among them. This irregularity and lack of nutrients intake was visible when height and weight of the participants was taken. When their housing and accommodation was evaluated, it was seen that $94.59 \%$ (245) of the total participants had just one room in their house so with the large number of family members with most having family members above 6 (Table 1). Among the participants reporting to have just 1 room in their house, 235 reported sharing that room with all of their family members. With $100 \%$ of the participants had indoor woodburning cooking facilities creating a congested area and a poor ventilation in the household.

\section{DISCUSSION}

About a quarter of children were found to have symptoms suggesting ARI, in which 13-60 months old group were identified as the highest hit group. Asthma, Allergy and number of people sharing the room were found to be the significant predictors of ARI. In addition, intake of protein at least 5 times in a week was found to be significant. Among, the correlation found between the variables, age with intake of dairy product, intake of protein with number of family members, intake of protein at least 5 times last week with intake of protein the previous day were among the major. However, no association was found between smoking and number of rooms in the house.
One of the key-findings of this study was 13-60 months old children being the risk group and some other studies performed around this region supports that findings (Azad 2009; Asghar et al. 2017; Cox et al. 2013; Goel et al. 2012). Another results that coincides with the previous studies done was number of people sharing room or overcrowding (Prajapati et al. 2011; Asghar et al. 2017; Goel et al. 2012;). Even though the result found on overcrowding supports the claim in some other studies, the finding is very specific to number of people sharing room. This study did not show any association between number of rooms in the house and ARI. However, in another study performed in Turkey, it was seen that there were no association among number of people sharing the room (Etiler \& Aktekin 2002) and ARI. Some other studies performed on ARI points out how due to malnutrition and immune function dysfunction (Rodríguez et al. 2011; Chalabi 2013; Cox et al. 2013) can lead to ARI. This also partially relates to this study as lack of intake of protein at least 5 times in a week has showed association with ARI, which can be a part of malnourishment. However, a study by Maharjan \& Sharma (2017) performed in Nepal found no association between the malnourishment and ARI.

The participants in this study, however, might have recall bias when asked about their eating habits or symptoms the child might be having. In addition to that, the findings from this study might not be application to all the Rohingya Refugee camps in Bangladesh as the living condition, location, eating habits and so on might vary. The results from this study might also not fit the finding from studies performed in other places outside as this was performed inside a refugee camps, therefore, are several other factors like, war-crisis, accommodation, lifestyle, lack of food, lack of medical facilities etc. that might differ from other places and might just be unique to the camp.

However, few of the things might help to change the ARI situation inside the camps includes administrative control that includes, awareness workshops on ARI, screening and detection, making few of the major medications available for the refugees. As overcrowding has been a major factor for ARI, public health and environmental engineers and work together to develop better housing facilities with proper ventilations to avoid the respiratory issues. Lastly, another major issue in the camp is 
being able to maintain hygiene. Therefore, workshops by the NGOs on importance of maintaining hygiene or washing hand after being in contact with a patient is very crucial. However, considering the scopes in these camps further studies should be conducted to find out more on the risk factors, their behaviours surrounding the disease/condition so that better preventative methods can be designed.

\section{CONCLUSION}

This study found the 13-60 months old children being the highest risk group from evaluation of the socio-demographic data. In addition, malnourishment especially inadequate intake of protein and overcrowding to be the risk factors associated with ARI. Even though concrete claims could not be made from the statistical analysis, the condition of the camp and need for attention was vivid. Therefore, some of the preventive methods can be used and larger studies should be conducted to identify the factors and their determinants for better strategies in this regard.

\section{ETHICAL CONSIDERATION}

The study was approval by the Ethical Review Committee (ERC) of Asian University for Women. The study maintained the privacy and confidentiality of the participants. Verbal consent was taken from legal guardian of the study participants. Before taking the consent the aim of the study was explained to the participants and information sheet was handed over for further communication if needed. They were given the chance to ask any questions regarding to the research. The participants were also had the freedom to withdraw from the research any time they wanted.

\section{ACKNOWLEDGEMENT}

We extend profound gratitude to the Department of Public Health and AUW for funding this research and we are also deeply grateful to BRAC for supporting the investigator throughout the data collection inside the camps.

\section{REFERENCES}

Asghar, S. A., Srivastava, M. R., Srivastava, J. P., Gupta, P., \& Zaidi, Z. H. (2017). Prevalence of acute respiratory infections among children under five years of age attending rural health training centre of Era's Lucknow Medical College and Hospital. International Journal Of Community Medicine and Public Health, 4(10), 3752-3756.

Azad, K. M. A. K. (2009). Risk factors for acute respiratory infections (ARI) among children under five years in Bangladesh. J Sci Res, 1(1), 72-81.

Banda, B., Mazaba, M. L., Mulenga, D., \& Siziya, S. (2016). Risk factors associated with acute respiratory infections among under-five children admitted to Arthur's Children Hospital, Ndola, Zambia. Asian Pac. J Health Sci, 3, 153-159.

Cardoso, A. M., Coimbra Jr, C. E., \& Werneck, G. L. (2013). Risk factors for hospital admission due to acute lower respiratory infection in Guarani indigenous children in southern Brazil: a population-based casecontrol study. Tropical Medicine \& International Health, 18(5), 596-607.

Chalabi, D. A. K. (2013). Acute respiratory infection and malnutrition among children below 5 years of age in Erbil governorate, Iraq.

Cox, M., Rose, L., Kalua, K., de Wildt, G., Bailey, R., \& Hart, J. (2017). The prevalence and risk factors for acute respiratory infections in children aged 0-59 months in rural Malawi: A cross-sectional study. Influenza and Other Respiratory Viruses, 11(6), 489-496. http://doi. org/10.1111/irv.12481.

Etiler, N., Velipasaoglu, S., \& Aktekin, M. (2002). Incidence of acute respiratory infections and the relationship with some factors in infancy in Antalya, Turkey. Pediatrics international, 44(1), 64-69.

Gahlot, A., Kumar, S., \& Som Nath, M. P. (2015). ARI in underfive children with associated risk factors

Goel, K., Ahmad, S., Agarwal, G., Goel, P., \& Kumar, V. (2012). A cross sectional study on prevalence of acute respiratory infections (ARI) in under-five children of Meerut District. India. J Comm Med Health Educ, 2(9), 176.

IOM. (2017). Bangladesh (Rohingya Influx) Health Situation Report. Retrieved from https://iom.org.bd/wp-content/uploads/2017/10/ IOM-CXB-Heath-Bulletin-Oct-2017.pdf

Maharjan, PL., \& Sharma, Y. (2017). Prevalence and Determinants of Acute Respiratory Infection among Children under Age Five in Gorkha Municipality, Gorkha. Global journal of Pharmacy \& pharmaceutical Science.

Prajapati, B., Talsania, N., \& Sonaliya, K. N. (2011). A study on prevalence of acute respiratory infections (ARI) in under five children in urban and rural communities of Ahmedabad district, Gujarat. Natl J Community Med, 2(2), 255-9.

Rodríguez, L., Cervantes, E., \& Ortiz, R. (2011). Malnutrition and gastrointestinal and respiratory infections in children: a public health problem. International journal of environmental research and public health, 8(4), 1174-1205

World Health Organization. (1987). ACUTE RESPIRATORY INFECTIONS (ARI) AND DIARRHOEAL DISEASES/62 (42), 315 - 316. http://www. who.int/iris/handle/10665/226456. 